\title{
EMOTIONAL INTELLIGENCE AS A DETERMINANT OF LEADERSHIP POTENTIAL
}

\author{
ANITA D STUART \\ ANDREA PAQUET \\ Department of Psychology \\ Rand Afrikaans University
}

\begin{abstract}
Emotional intelligence scores of employees of a financial institution who displayed leadership potential $(\mathrm{n}=31)$ were compared with scores of a group who displayed little leadership potential. Leadership was rated by ascertaining the presence of transformational behaviour. All rated employees completed an emotional intelligence scale. Results indicated that the factors of optimism and self-actualisation were significantly higher for the leader group. The non-leader group indicated higher scores on the positive impression scale, indicating possible positive skewing of results for that group. Generally, the research data indicates a link between the fundamental postulates of transformational leadership theory and emotional intelligence.
\end{abstract}

\section{OPSOMMING}

Emosionele intelligensie-tellings van'n groep werknemers binne ' $n$ finansiële instelling wie leierskapspotensiaal getoon het $(\mathrm{n}=31)$ is vergelyk met ' $\mathrm{n}$ groep wat min leierskapspotensiaal getoon het. Leierskapspotensiaal is bepaal op grond van die teenwoordigheid van transformasionele gedrag. Alle werknemers wat gemeet is het 'n emosionele intelligensieskaal voltooi. Resultate toon dat optimisme en selfaktualisasie beduidend hoër was vir die leiergroep. Die nie-leiergroep het hoër tellings getoon op die positiewe indruk-skaal, wat'n moontlike positiewe skeefheid van daardie groep se resultate aandui. Die navorsingsdata toon oor die algemeen'n koppeling tussen die fundamentele beginsels van transformasionele leierskapsteorie en emosionele intelligensie.

Leadership has been defined as the competencies and processes required to enable and empower ordinary people to do extraordinary things in the face of adversity. It is also the ability to constantly deliver superior performance to the benefit of oneself and the organisation. These definitions include being skilled in emotional competencies (Bennis \& Nanus, 1985, p. 223; Kelly, 1986, p. 12; Senge, 1991, p. 151).

This study focused on the emotional intelligence factors considered to be characteristic of effective leaders. Given the current South African political and business context, Charlton (1993) believes that emotional competencies are vital if organisations are to achieve excellence.

People who are unable to maintain a degree of control over their emotional life, fight inner battles that sabotage the ability for focused work and clear thoughts (Goleman, 1995). Unclear thinking and a lack of focus may in turn, contribute to decreased productivity and an overall decline in organisational success. Emotionally intelligent leaders with the ability to think clearly whilst being in tune with themselves and others, would thus be required to lead an emotionally intelligent organisation (Cooper \& Sawaf, 1997). Leaders may not necessarily occupy positions of authority in the organisation, yet even at lower organisational levels they lead by example. Otto (1995, p. 1) refers to such leaders as "little leaders". This study identified specific emotional competencies that may be characteristic of successful "little leaders".

\section{Leadership}

Much of the existing leadership research in these fields (e.g. Situational leadership theory (Hersey \& Blanchard, 1982)) emphasise that successful leadership implies the ability to cope with, and adapt effectively to environmental demands.

The transactional-transformational paradigm views leadership as either a matter of contingent reinforcement of followers by a transactional leader, or the moving of followers beyond their self interests for the good of the group, organisation or society by a transformational leader. The transformational leader induces in others a greater awareness regarding issues of consequence. This heightening of awareness requires a leader with self-confidence, vision and inner strength to argue for what is seen by the leader as good and right, rather than an accepted societal norm (Lewis, 1996).

Leadership has been described as the art of persuading people, rather than dominating them (Charlton, 1993; Goleman, 1995; Locke, 1991). Bass (1990, p. 68) suggests that the personal attributes, which enable an individual to exercise transformational leadership, include both "vision" and the capacity to convey that vision to others, even in the face of opposing conventional wisdom. These attributes equip the leader to argue what he or she sees as right and good, not for what is popular or acceptable according to established wisdom of the time (Bass, 1990; Burns, 1978).

\section{Emotional Intelligence}

Psychologists have been attempting to categorise and define intelligence for many years. Emotional intelligence adds new understanding to the concept of human intelligence, as it expands the capacity to measure one's general and overall intelligence (Bar-On, 1992). Broadly speaking, emotional intelligence addresses the emotional, personal, social and survival dimensions of intelligence, which are often more important for daily functioning than the more traditional cognitive aspects of intelligence. Emotional intelligence emphasises understanding one's self and others, relating to people and adapting to and coping with environmental demands. Salovey and Mayer (1990) state that emotions are primarily motivating forces, which arouse, direct and sustain activity. Emotional life can be handled with greater or lesser skill and requires a unique set of competencies

As emotional intelligence is a vital factor in determining ones ability to succeed in life and is said to directly influence one's psychological well-being or overall degree of emotional health (Bar-On, 1996b), it can be postulated that emotional health should also have some impact on the presence or absence of leadership ability.

Vision, self-confidence and inner strength are also indicators of emotional intelligence. Lewis (1996, p. 801) refers to the transformational leader's "inner strength". They argue that only those individuals who have achieved psychological definition, can exercise the independence needed to transcend interpersonal loyalties and organisational pressures in setting forth a transformational vision (Lewis, 1996).

It is postulated that more emotionally intelligent individuals, 
are those who are able to recognise and express their emotions, who possess positive self-regard and are able to actualise their potential capacities and lead fairly happy lives. They are able to understand the way others feel and are capable of making and maintaining mutually satisfying and responsible interpersonal relationships without becoming dependent on others (BarOn, 1992, 1996b; Goleman, 1995; Salovey \& Mayer, 1990). Such people are generally optimistic, flexible, realistic, and fairly successful in solving problems and coping with stress without losing control.

\section{Leadership and Emotional Intelligence}

The shift in leadership capacity is the result of specific, growing changes in business life in general, and the realities of managing increasingly brief, fast-paced, trusting, collaborative and innovative human interactions at work. Excessive emotions can temporarily disrupt reasoning or analysis, but recent research suggests that too little emotion can be even more destructive to a career or company (Damasio, 1994).

Studies reveal that emotions are a vital "activating energy" for ethical values such as trust, resilience and integrity. Emotions also provide the energy for social capital which represents an individual's ability to build and maintain trusting, profitable business relationships (Whitney, 1996). At the center of these traits is something every leader must have: the capacity to create excitement (Cooper \& Sawaf, 1997). This coincides with Goleman's (1995) observation that emotional intelligence includes the ability to motivate self and others, as well as the observation that charisma is a vital ingredient for successful leadership.

It also points to the importance of optimism in leadership. Because optimism is said to protect against depression (Seligman, 1990), it can be speculated that this thinking style has a direct effect on emotions. If optimism raises achievement levels whilst enhancing physical well being, those effects are likely to stimulate positive emotions and produce persistence in the face of setbacks.

Persistence also forms part of self actualisation. Bar-On (1992) describes self-actualisation as the ability to realise one's potential capacities which is characterised by becoming involved in pursuits that lead to a meaningful, rich life. This involves working on oneself and persisting to realise individual goals. Persistence is also characteristic of optimists and the literature would support the fact that the optimists also strive for selfactualisation. This means coming to know unique individual purpose by identifying specific talents and aligning them in the service of a calling in life. Research indicates that only when people have discovered their unique potential and purpose are they able to overcome obstacles and meet the challenges of success (Charlton, 1993; Cooper \& Sawaf, 1997; Munroe, 1993).

\section{Objective}

The purpose of this investigation is to determine whether individuals of non-managerial status who are identified as leaders, show greater emotional competence than those individuals (of the same organisational level) who display few, if any, leadership qualities. This study aimed to contribute to evidence that may influence decision makers, who as yet, remain skeptical about the concept of emotional competence which is not as tangible as capital profit and loss or sales figures, but may have an astounding impact on organisational success.

\section{METHOD}

\section{Participants}

From a group of 220 employees from lower hierarchical levels of a large bank in Johannesburg, 31 employees, who occupy similar positions, were identified by their immediate managers or supervisors as leaders by means of the Multi Factor Leadership Questionnaire (MLQ). Thirty-one employees were also identified as non-leaders using the same questionnaire and the same group of 220 people.
The 62 subjects comprised of 59 females and 3 males (leader group only). The average age was 33, with a range of 21 to 54 years. Initially the aim of the study was to select only female employees to control for possible differences due to gender. Three males, however, had been forwarded as their managers completed the leadership questionnaires. On scanning the leadership questionnaires it was discovered that the high scores of the three males made them ideal candidates for the leader group and contributed to greater discrimination between the leader and non-leader groups. As there was a shortage of leaders, the investigator decided to include them in the study. All employees were English-speaking with a minimum educational level of matric. Only employees between the bands CSS06-CSS08 (i.e. junior employees) were selected, according to the Hay job evaluation system. The makeup of the groups according to race was random, but did appear to reflect the makeup of the organisation as a whole. Combined totals of both groups included 42 Whites, 5 Indians, 12 Coloureds and 3 Black participants. The selected occupants included clerical and administrative occupations and/or customer occupations.

\section{Measuring Instruments}

Selection instrument

The Multi Factor Leadership Questionnaire (MLQ) provides a systematic means of measuring specific leadership factors (Bass \& Avolio, 1997). Although traditionally used for "labelled" or senior leaders, this study applied the same principles to lower level employees in organisations. At the ineffective end of the range, the Multi Factor Leadership Questionnaire (MLQ) assesses perceptions of leadership behaviours that represent avoidance of responsibility and action (laissez-faire). At the most effective end of the range, the MLQ assesses perceptions of leadership behaviours that generate the higher order developed and performance effects, namely transformational leadership.

In other research studies (Bass \& Avolio, 1997; Gasper, 1992) transformational leadership has been associated with higher levels of effectiveness and greater satisfaction. Such leaders are promoted more frequently, develop associates to higher levels of individual and group potential, generate better pro-ductivity rates, produce more innovative products, receive more patents for work produced by their people, reduce burnout and stress on the job, receive higher levels of volunteer effort from associates, and lead members in units who are more cohesive, who are more committed, and who perform more effectively under stress (Bass \& Avolio, 1994).

As this study was concerned with emotional competence and the quality of leadership, transformational leadership was adopted as a selection criterium to group the leader and nonleader groups.

\section{Measuring instrument}

The Emotional Quotient Inventory (EQ-i) (Bar-On, 1996a) measures the following factorial components of emotional intelligence, namely assertiveness, self regard, self actualisation, independence, interpersonal relationship, social responsibility, problem solving, reality testing, flexibility, stress tolerance, impulse control and happiness. Three additional factors (emotional self-awareness, empathy and optimism) have been added and are presently being studied to see how they relate to each other, to the other factors and to the larger concept of emotional intelligence itself. Two additional subscales to determine faking good and bad namely positive impression and negative impression form part of EQ-i.

The results render a total EQ score with a score of 100 as the average with standard deviations increasing and decreasing from 100 by 15 points respectively. The total EQ score is then broken down into 17 different content scale scores. These can be clustered into five groups of sub-EQ scores (intra-personal, interpersonal, adaptability, stress management and general mood), but this was not utilised in the present study. 
TABLE 1

SIGNIFICANCE OF DIFFERENCES BETWEEN LEADERS AND

NON-LEADERS REGARDING THE 17 EQ-I TEST SUBSCALES

\begin{tabular}{|c|c|c|c|c|c|c|c|c|c|}
\hline \multirow[b]{2}{*}{ Variables } & \multicolumn{2}{|c|}{ Leaders $N=31$} & \multicolumn{2}{|c|}{ Non-leaders $N=31$} & \multirow[t]{2}{*}{ F - Ratio } & \multirow{2}{*}{ p-Ratio } & \multicolumn{3}{|c|}{$t-$ test for equality of $X$} \\
\hline & $\mathbf{x}$ & SD & $\mathbf{x}$ & SD & & & $\mathbf{t}$ & df & p-value \\
\hline Problem Solving & 106.765 & 12.244 & 103.084 & 12.899 & 0.004 & 0.953 & 1.152 & 60.000 & 0.254 \\
\hline Social Responsibility & 100.587 & 15.898 & 101.361 & 14.777 & 0.000 & 0.990 & -0.199 & 60.000 & 0.843 \\
\hline Happiness & 94.690 & 12.289 & 98.167 & 16.021 & 2.479 & 0.121 & -0.958 & 60.000 & 0.342 \\
\hline Independence & 102.235 & 14.620 & 102.032 & 12.885 & 0.758 & 0.388 & 0.058 & 60.000 & 0.954 \\
\hline Stress Tolerance & 104.310 & 11.898 & 98.977 & 15.009 & 1.623 & 0.208 & 1.550 & 60.000 & 0.126 \\
\hline Self-Actualisation & 98.290 & 14.873 & 90.348 & 14.538 & 0.343 & 0.560 & 2.126 & 59.969 & 0.038 * \\
\hline Assertiveness & 100.394 & 15.569 & 97.923 & 15.707 & 0.199 & 0.657 & 0.622 & 60.000 & 0.536 \\
\hline Reality Testing & 98.019 & 12.601 & 100.761 & 11.508 & 0.012 & 0.912 & -0.895 & 60.000 & 0.375 \\
\hline Interpersonal Relationship & 95.145 & 15.845 & 96.290 & 17.066 & 0.122 & 0.718 & -0.274 & 60.000 & 0.785 \\
\hline Self-Regard & 99.100 & 11.039 & 104.129 & 13.206 & 1.047 & 0.310 & -1.627 & 60.000 & 0.109 \\
\hline Impulse Control & 98.526 & 16.041 & 102.842 & 12.748 & 2.367 & 0.129 & -1.173 & 60.000 & 0.245 \\
\hline Flexibility & 99.035 & 12.948 & 100.897 & 17.007 & 4.307 & 0.042 & -0.485 & 60.000 & 0.630 \\
\hline Self Awareness & 96.213 & 11.656 & 95.455 & 15.899 & 2.109 & 0.152 & 0.214 & 60.000 & 0.831 \\
\hline Empathy & 99.526 & 17.364 & 97.277 & 14.594 & 0.828 & 0.367 & 0.552 & 60.000 & 0.583 \\
\hline Optimism & 102.710 & 14.551 & 93.865 & 14.905 & 0.007 & 0.934 & 2.324 & 57.889 & 0.024 * \\
\hline Positive Impression & 99.530 & 11.504 & 106.484 & 9.907 & 1.231 & 0.272 & -2.551 & 58.709 & 0.013 * \\
\hline Negative Impression & 102.568 & 12.535 & 99.613 & 11.608 & 0.106 & 0.745 & 0.963 & 60.000 & 0.339 \\
\hline
\end{tabular}

$\star=$ Significant at $5 \%$ level

Wilks' coefficient lambda value $=0.564$

F Value $=1.192$

p Value $=0.045$

TABLE 2

VARIABLES EXTRACTED IN ORDER OF INCLUSION ACCORDING TO THE DISCRIMINANT ANALYSIS TECHNIQUE

\begin{tabular}{|c|c|c|c|c|c|}
\hline Variables & Tolerance & F to remove & Wilks' lambda & Degrees of Freedom & Significance \\
\hline Positive Impression & 0.962 & 2.880 & 0.708 & 1.580 & 0.015 \\
\hline Self-Actualisation & 0.729 & 4.796 & 0.731 & 2.570 & 0.003 \\
\hline Self-Regard & 0.604 & 9.922 & 0.794 & 3.560 & 0.001 \\
\hline Optimism & 0.633 & 6.075 & 0.747 & 4.550 & 0.000 \\
\hline
\end{tabular}

\section{Procedure}

The Multi Factor Leadership Questionnaire was distributed to 250 junior managers and supervisors. The Human Resource representatives for the divisions participating in the study, briefed senior management as to the purposes of the study and obtained permission for the distribution of the questionnaires. The questionnaire was accompanied by a cover letter, which briefly explained how to complete the questionnaire and to whom to return it. These managers and supervisors rated their immediate subordinates and returned the questionnaires to their Human Resources representatives. Complete confidentiality and anonymity was guaranteed. Of the 250 questionnaires distributed, 220 were completed and returned.

All 220 employees rated by their superiors on the leadership questionnaire were asked to complete the Emotional Quotient Inventory (EQ-I) (Bar-On, 1996a). Employees attended a group session (approximately 15 people in a group), where the investigator supervised the completion of the 45-minute EQ-I questionnaire.

Groups were selected through the identification of the highest scores or strongest indicators of transformational leadership behaviour (in the case of the 31 leaders) and the lowest scores or lack of transformational leadership behaviour (in the case of the 31 non-leaders).

\section{RESULTS}

The results of this study indicated statistically significant differences between Leaders and Non-leaders on the following EQ test subscales, namely; optimism self-actualisation and positive impression as indicated in Table 1.

Results of a stepwise discriminant analysis indicated that four variables, namely positive impression, self-actualisation, self-regard, and optimism, were the only variables out of a total of 17 variables which statistically significantly contributed to the discrimination between the two criterion groups.
In order to ascertain the contribution prediction of the variables to the two criterium groups, a discriminant classification function was calculated. A total of $75,9 \%$ of the subjects for Group 1 (leaders) was correctly classified by the four variables.

TABLE 3

CLASSIFICATION RESULTS

\begin{tabular}{lccc}
\hline Group & Correctly classified $\%$ & Incorrectly classified $\%$ & Total $\%$ \\
\hline Group 1 & 75,9 & 24,1 & 100.0 \\
Group 2 & 25,8 & 74,2 & 100.0 \\
\hline
\end{tabular}

\section{DISCUSSION}

As expected from previous research, a statistically significant difference in the degree of optimism between leaders and non-leaders was found. Although specific studies regarding the relationship between leadership ability and optimism do not appear to have been conducted, other research indicates that optimists perform much better in school, college/university, at work and on the sports field (Seligman, 1990). Optimists are said to constantly exceed aptitude test predictions, their health is usually better, they age well, and, according to evidence, may even live longer (Seligman, 1990).

As leaders are often achievers at work, an attitude of optimism would appear to be an important indicator of potential for success at the lower levels in organisations.

Self-actualisation ranked significantly higher amongst the leader group. Despite wide individual and group differences in human motives, there does appear to be a common core of psychological strivings related to maintenance and actualisation (Locke, 1991). Striving for influence through leadership may be one way of meeting self-actualisation needs. Selfactualisation involves creating order and predictability in an environment in order to work out an intelligent response to 
it. Leaders may perceive themselves to have greater control over their environment. When a person is recognised as being a leader this may contribute to and meet the needs of adequacy, competency and security.

One could argue then, that the process of empowering employees through allowing them greater control and mastery at work assists individuals in their own self-actualisation process, thus giving them the opportunity to display previously undemonstrated leadership behaviours. Emotional intelligence involves tuning in to the higher needs of others as well as tuning in to ones own personal growth needs. Part of self-actualisation may be the ability to find one's own unique potential and purpose. Once one has a purpose, motivation and energy are generated and form foundations for leading other (Cooper \& Sawaf, 1997).

In order to understand the process of self-actualisation in others, the leader would need to have understood and experienced his/her own self-actualisation process. Follower support may contribute to the leader meeting needs of be-longing, approval and love. Maslow's $(1971 ; 1978)$ well-known need hierarchy states that the lowest level of unmet needs at a given time in the motivational repertoire occupies the person's principle attention and efforts, until that particular frustration is resolved. Maslow (1978) extended this conception to the idea that the highest level of human motives, those associated with self-actualisation, are attained only by those individuals who have successfully resolved needs, both biological and self-derived, at lower levels. This would imply that the leader group of the study might have been able to satisfy more lower order needs than the non-leader group.

Leadership requires constantly meeting challenges and overcoming obstacles. It may be expected that the leader group must have been able to identify at least one specific, unique strength and talent as the definition of self-actualisation states (Bar-On, 1992). Having a clear career and life plan is also an indicator of a developing actualisation process. If a leader is to deploy and maximize his/her full potential a deep guiding purpose, vision, and sense of destiny for one's existence should be present (Munroe, 1993).

The need to portray a positive impression (i.e. a tendency to display social desirability) was significantly higher among the non-leader group than among the leader group. Given these results, it may be postulated that all the results for the nonleader group may be positively skewed as the positive impression score indicates an overall positive skewing of results. This need to please or impress others may be indicative of an external locus of control. The individuals may not be able to go with the courage of their convictions, preferring to conform to the accepted organisational norms. Leaders, on the other hand, are seen as creative non-conformists who are at times prepared to 'buck the system' (Bass, 1990; Charlton, 1985; Otto, 1995; Senge, 1991)

This study has considered the emotional intelligence of identified leaders and compared them with the emotional intelligence of identified non-leaders. Transformational leadership includes the conceptions of leadership as exchanges of reinforcements by the leader that are contingent on followers' performance. This type of leadership requires knowing the self whilst having the ability to empathise with and grow followers.

Emotional intelligence involves being aware of one's feelings as they occur. This awareness of emotions is the main emotional competency on which others, like self-control, build. This study identified the factors of optimism and self-actualisation as being significant determinants of leadership potential, succeeding as well to identify emotional intelligence factors which would $75,9 \%$ successfully discriminate between leaders and non-leaders.

However, this study is subject to some important limitations. Firstly, the selection and measuring instruments are subject to some criticisms. The EQ-I is the first and only instrument to measure factors of emotional intelligence and its psychometric soundness can only be improved over time and with continuous use. Furthermore, the Multi factor Leadership Questionnaire was originally developed to measure leadership qualities of people in leadership positions. However, as there does not appear to be a psychometrically sound instrument to measure leadership independent of current leadership status, it was decided to apply the MLQ to this study. The data then generated by the present investigation may be limited and indicative, rather than imperative.

Secondly, the group make-up did not control for many biographical factors and the sample remain small. The data is therefore limited to the demographic confines of the population.

Given the limitations, it would be expected that in a larger study, other significant factors might be identified to link emotional intelligence and leadership.

Areas for future research include verification of the EQ-I and an investigation into interrelationships between sub-scales. Future research should also include other industries and environments to test possible generalisation of this study.

Corporations have gone through a radical revolution in this century, where the rigid hierarchy and managerial domination and manipulation of the past are no longer rewarded (Bass, 1997; Charlton, 1993). The key to future corporate success lies in the utilisation of interpersonal skills. This requires being skilled in the basic emotional competencies of being attuned to those one is dealing with, being able to handle disagreements so they don't escalate and having the ability to move into intuitive flow states whilst working (Goleman, 1995). Even employees who are not in labeled positions of authority, have a responsibility to themselves and others. It is those individuals who embrace the challenge to face who they are, that are more likely to possess leadership ability.

$$
\begin{gathered}
\text { "The discovery of self . . . is the birth of leadership" } \\
\text { (Munroe, 1993, p. 32) }
\end{gathered}
$$

\section{REFERENCES}

Bar-On, R. (1992). The development of a concept and test of emotional intelligence. An unpublished manuscript.

Bar-On, R. (1996a). The Emotional Quotient Inventory (EQ-I): A test of emotional intelligence. Toronto: Multi-Health Systems.

Bar-On, R. (1996b). The EQ-I manual. Toronto: Multi-Health Systems.

Bass, B.M. (1990). Bass \& Stogdill's handbook of leadership. New York: The Free Press.

Bass, B.M., \& Avolio, B.J. (1994). Improving organizational effectiveness through transformational leadership. Newbury Park, CA: Sage Publications.

Bass, B.M., \& Avolio, B.J. (1997). Full range leadership development Manual for the multifactor leadership questionnaire. California: Mind Garden.

Bennis, W.G., \& Nanus, B. (1985). Leaders: The strategies for taking charge. New York: Harper \& Row.

Burns, J.M. (1978). Leadership. New York: Harper Collins.

Charlton, G. (1993). Leadership: The human race. South Africa: Juta and Co, Ltd.

Cooper, R., \& Sawaf, A. (1997). Executive EQ-emotional intelligence in business. United Kingdom: Orion Publishing Group.

Damasio, A.R. (1994). Descartes'error: Emotion, reason and the human brain. New York: Putnam.

Gasper, S. (1992). Transformational leadership: An integrative review of the literature. Doctoral Dissertation, Western Michigan University, Kalamazoo, MI.

Goleman, D. (1995). Emotional intelligence. New York: Bantam Books.

Hersey, P., \& Blanchard, K. (1982). Management of organisational behaviour: Utilising human resources. Englewood Cliffs: Prentice Hall. 
Kelly, G. (1986). Chief Executive Officers' Success and the Development of High Potential Employees. Unpublished MBA Research Report. Johannesburg: University of the Wit-watersrand.

Lewis, P (1996). Transformational change using stratified systems theory. International Journal of Public Administration, 19(6), 801826.

Locke, E.A. (1991). The Essence of Leadership: The four keys to leading successfully. New York: Lexington.

Maslow, A.H. (1971). Farther reaches of human nature. New York: Viking Press.

Maslow, A.H. (1978). Toward a psychology of being. New York: Harper and Row.
Munroe, M. (1993). Becoming a leader everyone can do it. Canada: Pneuma Life Publishing.

Otto, M. (1995). Are there leaders lurking in your organization? P \& I, (34), 17.

Salovey, P. \& Mayer, J.D. (1990). The Intelligence of Emotional Intelligence. Intelligence, 17, 433442.

Seligman, M.E.P.(1990). Learned optimism - how to change your mind and life. New York: Pocket Books.

Senge, P. (1991). The fifth discipline - the art and practice of learning organisations. New York: Doubleday Currency.

Whitney, J.O. (1996). The economics of trust. New York: McGraw-Hill. 